\title{
Polymorphism analysis in some Algerian Opuntia species using morphological and phenological UPOV descriptors
}

ccreative

Botanical Sciences

95 (3): 391-400, 2017

DOI: 10.17129/botsci.887

Copyright: (c) 2017 Hadjkouider $e$ $a l$. This is an open access article distributed under the terms of the Creative Commons Attribution License, which permits unrestricted use, distribution, and reproduction in any medium, provided the original author and source are credited.

All authors contributed equally during the preparation of this work.

${ }^{1}$ Department of Agricultural Sciences. Faculty of Nature and Life Sciences. Saad Dahlab University, Blida, Algeria.

2 Department of Agricultural Sciences, Faculty of Science, Mohamed Boudiaf University, M'sila, Algeria.

3 Institute of Biological, Environmental and Rural Sciences, Aberystwyth University, Ceredigion, UK.

${ }^{4}$ Laboratory of Management and Valorization of Natural Resources and Quality Assurance. University of Bouira, Bouira, Algeria

${ }^{5}$ Laboratory of Plant Molecular Physiology, Biotechnology Centre of Borj-Cédria, Hammam-lif, Tunisia.

* Corresponding author: bhadjkouider@gmail.com
Boubakr Hadjkouider ${ }^{1,2 *}$, Ammar Boutekrabt ${ }^{1}$, Bahia Lallouche ${ }^{2}$, Salim LAmINE $^{3,4}$, NéfIA ZOGHLAmI ${ }^{5}$

\section{Abstract}

Background: In the present study, we have investigated the morphological variation in a set of five Opuntia species from the Algerian steppes using 49 UPOV descriptors.

Questions: Which of the 49 descriptors that can be used as powerful estimators of the phenotypic diversity within Opuntia species? How is the morphological diversity patterned in Algerian Opuntia?

Species study/ Mathematical model: Opuntia ficus-indica, Opuntia amycleae, Opuntia streptacantha, Opuntia engelmannii, Opuntia robusta. Principal Components Analysis (PCA) and Hierarchical Cluster Analysis were used.

Study site: Four counties were studied located in the Algerian steppes. The present research was carried out during 2014.

Methods: 49 descriptors adopted by the International Union for the Protection of New Varieties of Plants (UPOV) were employed in the present research, where cladode, flower and fruit traits were used to determine the overall degree of polymorphism among 5 Opuntia species.

Results: Principal Component Analysis and Hierarchical Cluster Analysis indicated a consistent differentiation between all studied species. The relative magnitude of the first two PCA eigenvectors showed that 8 descriptors out of 49 were identified as the most important descriptors for the classification of the species. The dendrogram performed on the calculated Euclidean distances between all species pairs allowed the identification of 3 groups, unlike the PCA that identified 4 groups. The species Opuntia ficus-indica and Opuntia amycleae were identified as very close morphologically.

Conclusions: The present outcome represents a paramount step towards the fast selection of interesting species and for their best management and conservation.

Key words: Opuntia, diversity, multivariate analyses, clustering, UPOV.

\section{Resumen}

Antecedentes: En el presente estudio, hemos investigado la variación morfológica en un conjunto de cinco especies de Opuntia de las estepas argelinas utilizando 49 descriptores UPOV.

Preguntas: ¿Cuáles de los 49 descriptores que pueden ser utilizados como estimadores poderosos de la diversidad fenotípica dentro de las especies de Opuntia?

¿Cómo se modela la diversidad morfológica en el Opuntia Argelina?

Especie en estudio/ Modelo matemático: Opuntia ficus-indica, Opuntia amycleae, Opuntia streptacantha, Opuntia engelmannii, Opuntia robusta. Análisis de Componentes Principales (PCA) y un Análisis de Agrupamiento Jerárquico fueron usados

Sitio de estudio y fechas: Se estudiaron cuatro condados situados en la estepa argelina. La presente investigación se realizó durante el año 2014.

Métodos: En la presente investigación se utilizaron 49 descriptores adoptados por la Unión Internacional para la Protección de las Obtenciones Vegetales (UPOV), en los que se utilizaron características de cladodio, flor y fruto para determinar el grado global de polimorfismo entre 5 especies de Opuntia.

Resultados: Se aplicó un análisis multivariado, constituido por un análisis de componentes principales (PCA) y un análisis de agrupamiento jerárquico, cuyo resultado indicó una diferenciación consistente entre las especies estudiadas. Con base en la magnitud relativa de los dos primeros eigen-vectores del PCA se seleccionaron 8 de los 49 descriptores morfológicos como los más relevantes para la clasificación de las especies siendo los que más contribuyeron a la variación morfológica detectada. Dichos descriptores pertenecen a la lista de descriptores primarios establecida por la UPOV para la caracterización de Opuntia. El dendrograma obtenido aplicando el método de Ward (1963) para el cálculo de las distancias euclídeanas entre pares de poblaciones permitió identificar tres grupos distintos, mientras que el análisis PCA diferenció cuatro grupos. Por consiguiente, las especies Opuntia ficus-indica y Opuntia amycleae fueron identificadas como especies muy cercanas filogenéticamente.

Conclusiones: Estos resultados representan un avance crucial para la selección e identificación rápida de poblaciones de interés y una mejora para las estrategias de gestión y conservación.

Palabras clave: Opuntia, la diversidad, análisis multivariado, agrupación, UPOV. 
he Cactaceae are dicotyledonous angiosperms, most plentiful in the arid and semi-arid regions between $35 \mathrm{~N}$ and $35 \mathrm{~S}$ composed of about 2,260 accepted species (Taylor 1997). Among these, the genus Opuntia L. Mill. has as many as 215 species.

Opuntia has been exploited since the pre-Columbian times and is mainly present in North and South America, but has also been introduced into the Mediterranean basin, Middle-East, South Africa, India, Thailand and Australia. The species reached the Mediterranean basin during the $16^{\text {th }}$ century (Barbera 1995). Nevertheless, only towards the end of the $20^{\text {th }}$ century have large plantations been established, where only rough estimates of the worldwide plantation area (Zoghlami et al.2007) are allowed due to the absence of updated statistical data from countries in which this species is cultivated.

During the last decade, cacti (Opuntia ficus-indica) They have been used for almost 500 years as a fruit crop, a defensive hedge, and, more recently, as a fodder crop and as a standing buffer feed for drought periods; they can also play a key role in erosion control and land rehabilitation, particularly in arid and semi-arid zones, and as a shelter, refuge and feed resource for wildlife (Le Houérou 1996a).

Generally, the characterization of Opuntia genus is incomplete due to few morphological characters taken into account to classify them into the genus (Rebman \& Pinkava 2001); also, the inadequate descriptors have led to misclassification (Caruso et al.2010, Majure et al.2012), they usually lack botanical references and other data, which makes it difficult to properly document and register different varieties under the basis of a reliable classification procedure (Gallegos-Vázquez 2012). Several authors have analyzed morphological diversity in several plants (Lamine et al. 2014, Arteaga et al. 2015). In Opuntia, morphological investigations have been carried out in Brazilian (Uchoa et al. 1998), Chilean (Wang et al. 1998), Mexican (Reyes-Agüero et al. 2005, Muñoz-Urias et al. 2008, Gallegos-Vázquez et al. 2011, Gallegos-Vázquez et al. 2012, Martínez-González et al. 2015) and Moroccan genetic resources (El Finti et al. 2013).

In Algeria, several ha are cultivated with Opuntia, where Opuntia ficus-indica (L.) Mill., is an important fodder crop, mainly for sheep, during low feed availability periods following drought and dry seasons. Large plantations have recently been established in the region of Souk-Ahras (commune of Sidi Fredj), also near the region of Tebessa, for the objective of improving and rehabilitating the steppe and the marginal areas (Neffar et al. 2011). Despite the importance of Opuntia in the country, only few studies have been undertaken to characterize the nutritional value of the fruits and cladodes as important food crop and fodder (Hadj Sadok et al.2014), and the effect of the prickly pear plantation age on soil properties and vegetation cover (Neffar et al. 2011). Thus, studies that address the amount of morphological variation are still missing for Algerian Opuntia species.

Despite its great importance, some Opuntia species are threatened with extinction due to traditional agricultural practices unsuitable for their conservation and the negligence of some species. In addition, the morphological and genetic diversity of Opuntia have not been well assessed previously. The absence of such studies in Algeria motivated us to study the morphological and phenological polymorphism of these species and to determine the most discriminatory characteristics that allow separating this genetic richness.

In this study, we aim to assess the morphological diversity in five Opuntia species with potential agro-ecological values for human consumption present in the Algerian steppes, using 49 traits collected from cladodes, flowers and fruits following the International Union for the Protection of New Varieties of Plants (UPOV) guidelines. The phenotypic diversity among and within the species has been estimated to identify the traits that contribute most to the morphologic variation and classify the genotypes using PCA and hierarchical cluster analyses.

\section{Materials and Methods}

Plant material. Five Opuntia species of the subgenus Platyopuntia (Engelm.) Kreuz, Opuntia ficus-indica, Opuntia amycleae Ten., Opuntia engelmannii Salm-Dyck ex Engelm., Opuntia streptacantha Lem., and Opuntia robusta H.L.Wendl., were prospected from the Algerian steppes in Doukkara (Tébessa), Belaiba (M'sila), Mesrane (Djelfa) and Choucha (Laghouat) districts (Figure 1). In our study, we pre-considered $O$. amycleae as separate sepecies from $O$. 


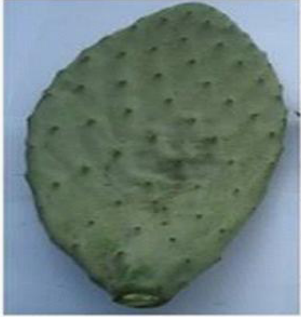

1

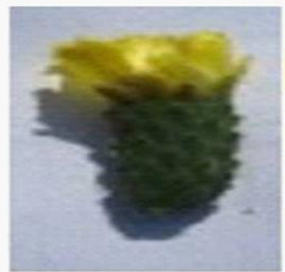

1

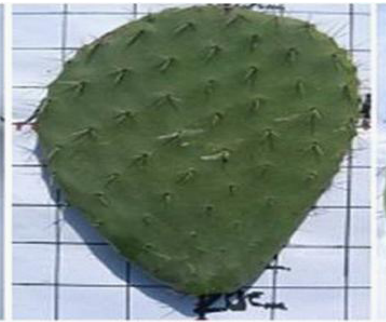

2

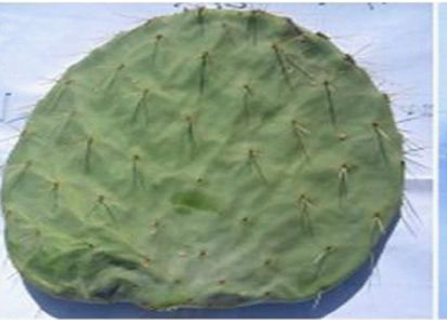

3

Cladodes

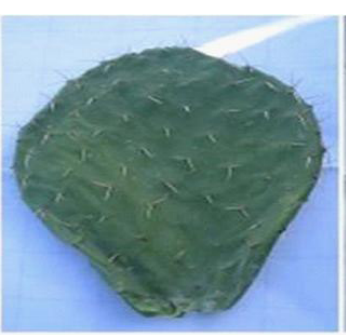

4

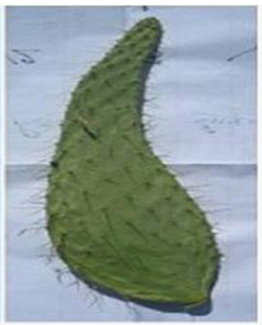

5

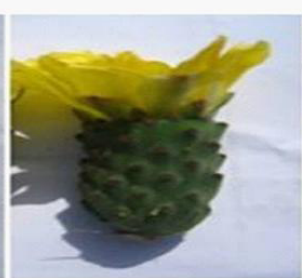

2

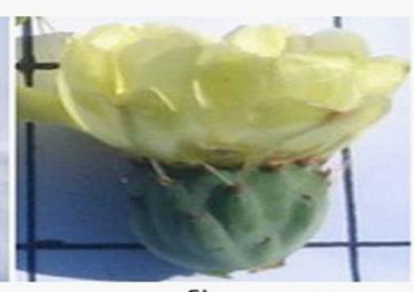

3

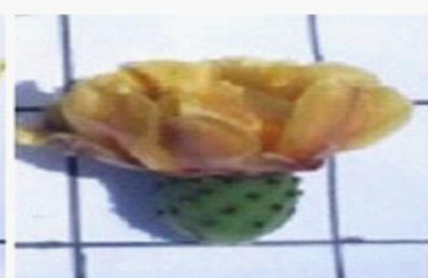

4

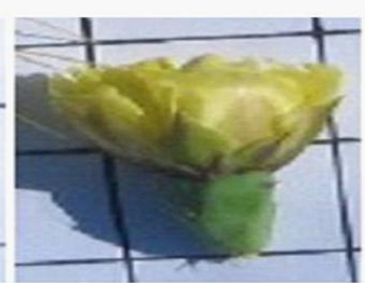

5
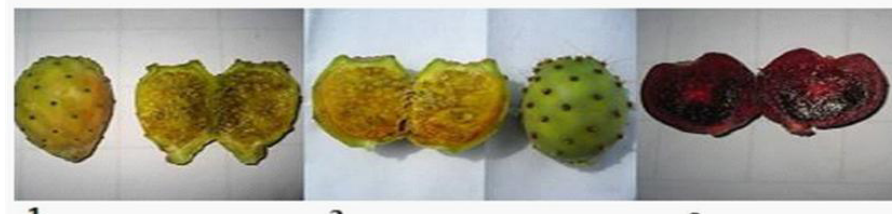

fruits
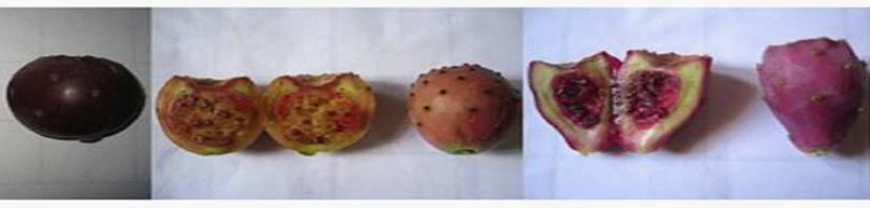

5

Figure 1. Algerian Opuntia species investigated in this study: 1: Opuntia ficus-indica; 2: Opuntia amycleae; 3: Opuntia robusta; 4: Opuntia streptacantha; 5: Opuntia engelmannii.

ficus-indica just to check the morphological similarity. However, several authors consider $O$. amyclaea as synonyms of $O$. ficus-indica, and they divided this latter species into two botanical forms: a) $O$. ficus-indica f. amyclaea (Ten.) Schelle, with presence of spines and b) O. ficusindica f. inermis (Web.) (Kiesling 1999), which is spineless. In the present work we adopted a random sampling method; the sampled species were then kept at the repository of the High Commissariat for Steppes Development (HCSD) and National Institute of Forestry Research (NIFR) in Algeria (Table 1).

Species analysis per species was applied to assess morphological variation, 10 individuals were scored, and from each individual 3 cladodes, 3 flowers and 3 fruits were investigated for their differences according to the 49 UPOV morphological descriptors (Table 2).

Morphological descriptors and data collection. Forty-nine major quantitative and qualitative traits, selected from the UPOV list (UPOV, 2006), comprising cladode, flower and fruit descriptors were measured and used to design a numbered-data matrix (Table 2). Ten individuals per species were evaluated for their morphological diversity across the 49 descriptors. Measurements were performed by the same two persons to avoid errors due to individual variations.

Statistical analysis based on the morphological diversity of cladode, flower and Opuntia fruits. Morphological and phenological data were analyzed by multivariate analyses and clustering using XLSTAT software (Addinsoft, www.xlstat.com). PCA was performed to identify species groups and to determine the axes and the characters significantly contributing to the variation. In this procedure, the similarity matrix was used to generate eigenvalues and scores for the species. The first two principal components, which accounted for the highest variation, were then used to plot two-dimensional scatter plots. Hierarchical cluster analyses (HCA) was carried out using Ward's minimum variance method as a clustering algorithm (Williams 1976) and squared Euclidean distances as a measure of dissimilarity (Ward 1963). 
Table 1. List of the five Algerian Opuntia species evaluated in this study with their agro-ecological characteristics.

\begin{tabular}{lccccc} 
Species & O. ficusindica & O. amycleae & O. streptacantha & O. robusta & O. engelmannii \\
\hline Code & OFI & OA & OS & OR & OE \\
Mains use & Fruit & Fruit & fruit & fruit & fodder \\
Commercial importance & very high & very high & very high & medium & low \\
Locality & Belaiba & Doukkara & Choucha & Mesrane & Mesrane \\
& $\left(M^{\prime}\right.$ sila) & (Tébessa) & $($ Laghouat) & (Djelfa) & (Djelfa) \\
Latitude & $35^{\circ} 36^{\prime}$ & $35^{\circ} 58^{\prime}$ & $34^{\circ} 8^{\prime}$ & $34^{\circ} 36^{\prime}$ & $34^{\circ} 36^{\prime}$ \\
Longitude & $05^{\circ} 17^{\prime}$ & $8^{\circ} 14^{\prime}$ & $3^{\circ} 01^{\prime}$ & $3^{\circ} 03^{\prime}$ & $3^{\circ} 03^{\prime}$ \\
Temp. min $\left(\mathrm{C}^{\circ}\right)$ & 13,0 & 10,1 & 9,36 & 9,47 & 9,47 \\
Temp. Max $\left(\mathrm{C}^{\circ}\right)$ & 24,3 & 22,3 & 23,0 & 23,3 & 23,3 \\
Precipitation $(\mathrm{mm})$ & 238,2 & 406,7 & 236,4 & 229 & 229 \\
Soil type & sandy/muck land & muck land & sandy land & sandy land & sandy land \\
Soil pH & 7.69 & 7.52 & 7.53 & 8.55 & 8.55 \\
Bioclimatic Floor & semi-arid & semi-arid & semi-arid & semi-arid & semi-arid \\
& mild winter & cold winter & cold winter & mild winter & mild winter \\
\hline
\end{tabular}

\section{Results}

Principal Component Analysis (PCA). The Principal Component Analysis (PCA) showed a high level of morphological variation between the five studied Opuntia species (Table 3). The first 2 axes of the PCA accounted for $67.217 \%$ of the total variation with the first component (PC1) explaining $38.239 \%$ of the total variation, while PC2 accounted for 28.978 .

Out of 49 morphological descriptors, 8 were identified as the most discriminating and useful for the classification of the Opuntia species. The contribution of all parameters to the definition of the first two PCA axes is given in table 3. The traits that best contributed to the first component variability were the following: time of beginning of flowering (0.229), time of harvest
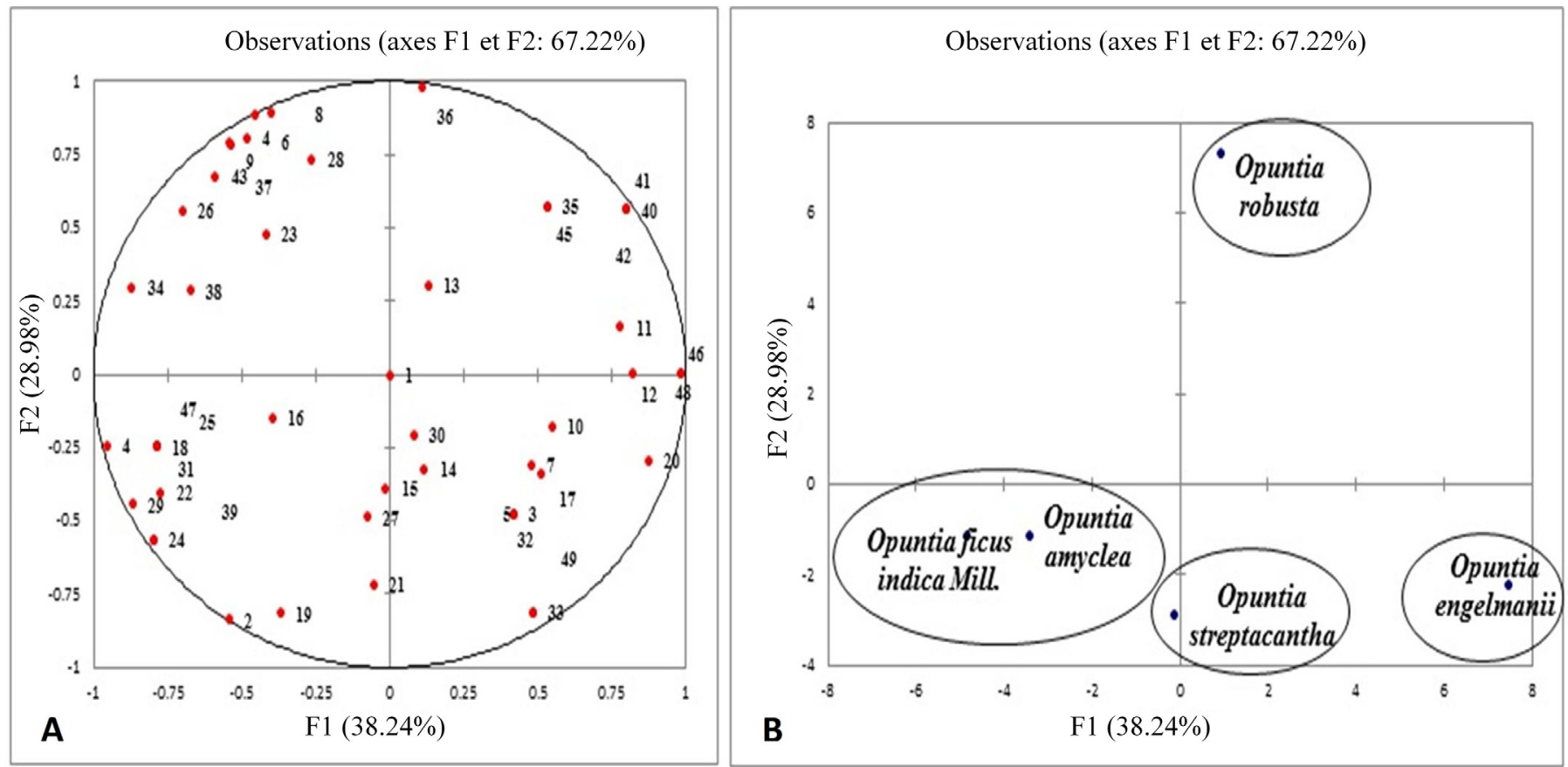

Figure 2. Principal Component Analyses showing: A) the contribution of the UPOV descriptors (from 1 to 49, see Table 2) to the obtained morphological variation; B) the distinction of all studied Opuntia species. 


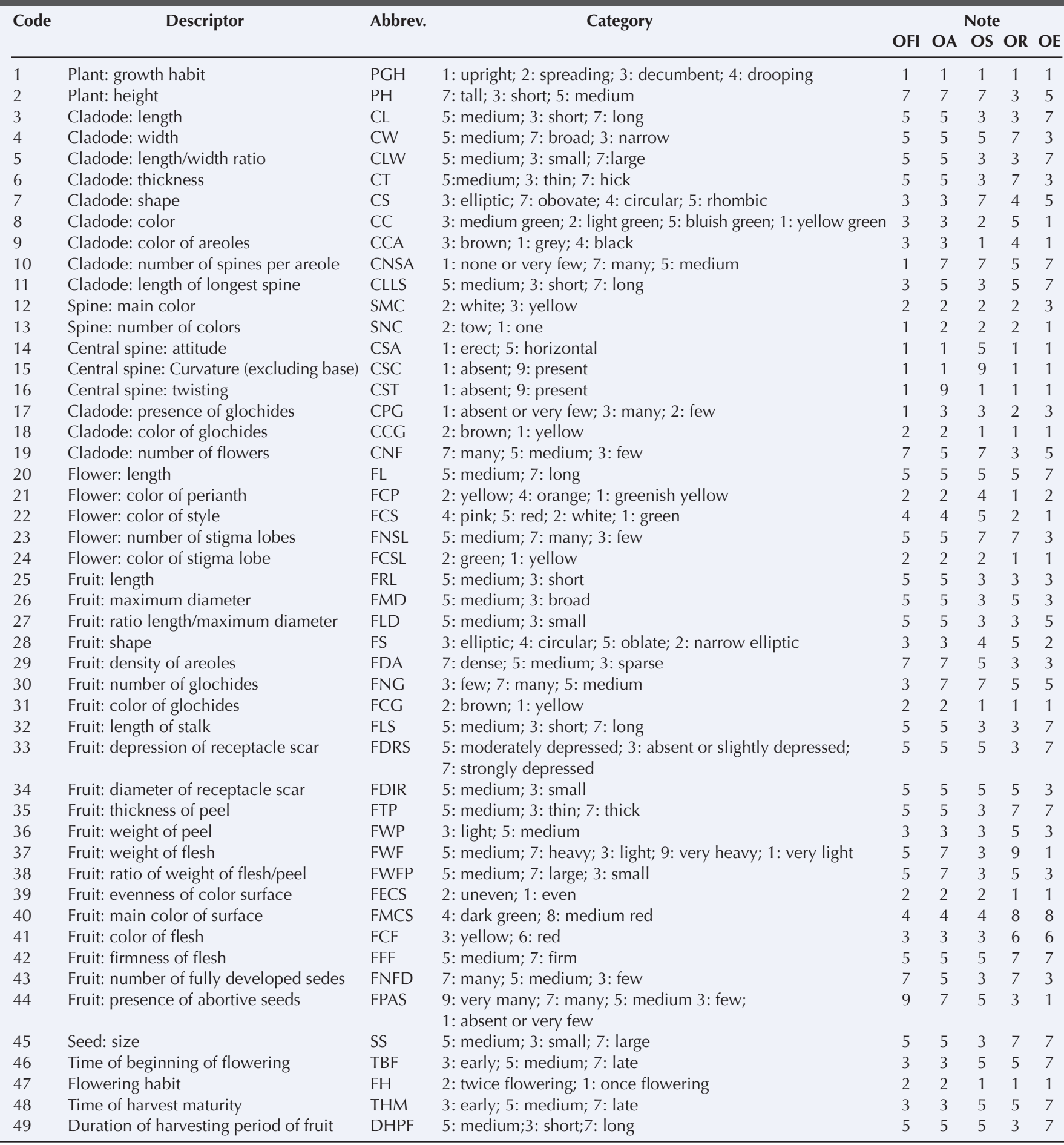

maturity (0.229), flower length (0.203), main spine color (0.191), main color of fruit surface (0.186), color of fruit flesh (0.186), firmness of fruit flesh (0.186), length of the longest spine per cladode (0.182). On the other hand, in the second PCA component, we obtained highly and positive correlation for the descriptions cladode width (0.217), cladode thickness $(0.239)$, cladode color (0.238), color of areoles per cladode (0.210), fruit shape (0.197), peel weight per fruit $(0.264)$, flesh weight per fruit $(0.212)$, and number of fully developed seeds per fruit $(0.181)$ (Table 3, Figure 2). 
Table 3. Definition the first two components of the PCA based on 49 UPOV morphological descriptors in five Opuntia species from Algeria.

\begin{tabular}{|c|c|c|c|}
\hline Principal components & PC1 & PC2 & PC3 \\
\hline Eigenvalue & 18.354 & 13.910 & 11.314 \\
\hline Variability (\%) & 38.239 & 28.978 & 23.570 \\
\hline$\%$ cumulative & 38.239 & 67.217 & 90.787 \\
\hline Morphological descriptors* & Eigenvalue & & \\
\hline 1 & 0.000 & 0.000 & 0.000 \\
\hline 2 & -0.127 & -0.224 & 0.016 \\
\hline 3 & 0.097 & -0.128 & -0.229 \\
\hline 4 & -0.113 & 0.217 & 0.100 \\
\hline 5 & 0.097 & -0.128 & -0.229 \\
\hline 6 & -0.094 & 0.239 & -0.061 \\
\hline 7 & 0.112 & -0.083 & 0.239 \\
\hline 8 & -0.107 & 0.238 & 0.013 \\
\hline 9 & -0.125 & 0.210 & -0.089 \\
\hline 10 & 0.127 & -0.048 & 0.123 \\
\hline 11 & 0.182 & 0.043 & -0.018 \\
\hline 12 & 0.191 & 0.001 & 0.061 \\
\hline 13 & 0.030 & 0.081 & 0.191 \\
\hline 14 & 0.027 & -0.086 & 0.279 \\
\hline 15 & -0.003 & -0.104 & 0.271 \\
\hline 16 & -0.093 & -0.040 & -0.064 \\
\hline 17 & 0.120 & -0.091 & 0.112 \\
\hline 18 & -0.184 & -0.066 & -0.161 \\
\hline 19 & -0.086 & -0.218 & 0.052 \\
\hline 20 & 0.203 & -0.079 & -0.116 \\
\hline 21 & -0.013 & -0.192 & 0.204 \\
\hline 22 & -0.181 & -0.107 & 0.146 \\
\hline 23 & -0.097 & 0.128 & 0.229 \\
\hline 24 & -0.186 & -0.151 & 0.061 \\
\hline 25 & -0.184 & -0.066 & -0.161 \\
\hline 26 & -0.163 & 0.149 & -0.127 \\
\hline 27 & -0.018 & -0.131 & -0.255 \\
\hline 28 & -0.062 & 0.197 & 0.185 \\
\hline 29 & -0.203 & -0.119 & -0.055 \\
\hline 30 & 0.019 & -0.055 & 0.182 \\
\hline 31 & -0.184 & -0.066 & -0.161 \\
\hline 32 & 0.097 & -0.128 & -0.229 \\
\hline 33 & 0.113 & -0.217 & -0.100 \\
\hline 34 & -0.203 & 0.079 & 0.116 \\
\hline 35 & 0.124 & 0.154 & -0.185 \\
\hline 36 & 0.025 & 0.264 & 0.042 \\
\hline 37 & -0.126 & 0.212 & -0.005 \\
\hline 38 & -0.157 & 0.076 & -0.117 \\
\hline 39 & -0.186 & -0.151 & 0.061 \\
\hline 40 & 0.186 & 0.151 & -0.061 \\
\hline 41 & 0.186 & 0.151 & -0.061 \\
\hline 42 & 0.186 & 0.151 & -0.061 \\
\hline 43 & -0.137 & 0.181 & -0.110 \\
\hline 44 & -0.223 & -0.064 & -0.039 \\
\hline 45 & 0.124 & 0.154 & -0.185 \\
\hline 46 & 0.229 & 0.001 & 0.043 \\
\hline 47 & -0.184 & -0.066 & -0.161 \\
\hline 48 & 0.229 & 0.001 & 0.043 \\
\hline 49 & 0.113 & -0.217 & -0.100 \\
\hline
\end{tabular}

*See table 2 .

The projection of the species on the plot delimited by the first two PCA axes, showed the classification of the species into four distinct groups (Figure 2). The first group (a) comprises Opuntia engelmannii a second group (b) includes two species, Opuntia ficus-indica and Opuntia amycleae situated at the negative side of the plot, Opuntia robusta constituted the third group (c) and Opuntia streptacantha constituted the fourth group (d). 


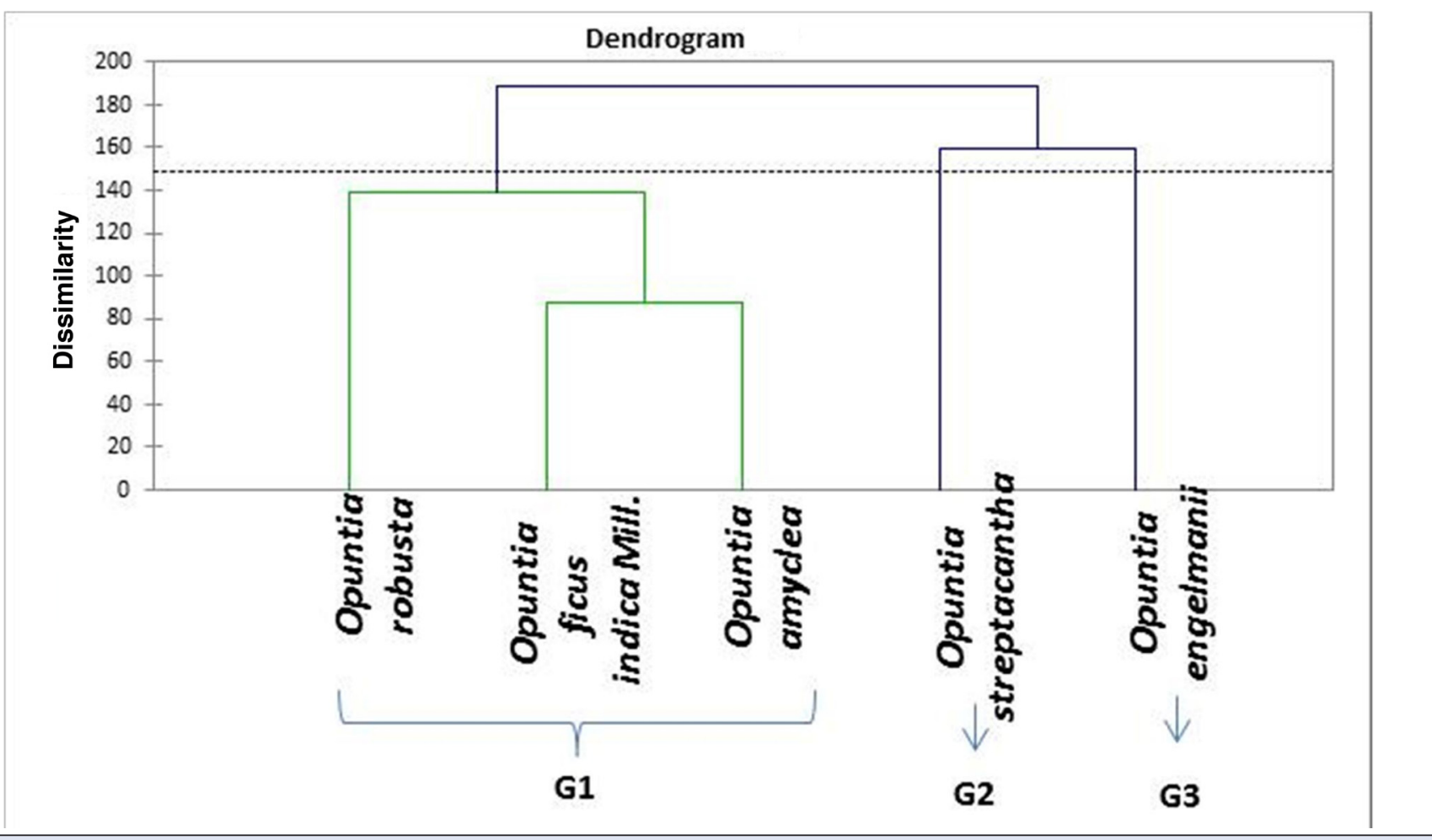

Figure 3. Dendrogram showing relationships between five Opuntia species in Algeria using 49 morphological descriptors (G1 and G2 stand for the identified groups).

Cluster Analysis. To understand how the 5 Opuntia species are structured a ward-derived dendrogram was constructed based on the data yielded by the 49 morphological descriptors (Figure 3). This allowed the identification of 3 groups, unlike the PCA and phenological that identified 4 groups (Figure 3). The first cluster (C1) was constituted by three species: Opuntia robusta (OR), Opuntia ficus-indica (OFI) and Opuntia amycleae (OA). Within this group, Opuntia robusta was very different and characterized by a high number of fully developed seeds per fruit, broad thick bluish green cladodes, with black areoles, oblate fruit shape, medium peel weight and heavy fruit flesh weight (Figure 3). Opuntia ficus-indica and Opuntia amycleae were the closest as both were characterized by brown glochides, medium flower length, pink flower style, green stigma lobes, a medium ratio of length/maximum diameter of fruit, dense areoles, medium diameter of the receptacle scar.

Opuntia streptacantha formed the second cluster (C2) having an obovate cladode shape, two types of color spines, a horizontal attitude of the central spine, orange colored perianth, high number of stigma lobes and glochides.

The third group (C3) was constituted by Opuntia engelmannii (OE) that is distinguishable particularly, by late time of beginning of flowering and harvest maturity, long flower length, yellow spine color, medium red fruit surface, red fruit firm flesh, high number of long spines per areole per cladode, and large amount of many glochides (Figure 3).

\section{Discussion}

The present study revealed the morphological and phenological diversity in the five dominant species of Opuntia grown in Algerian steppes using 49 morphological descriptors.

The set of the UPOV descriptors used here allowed, for the first time, the characterization of the morphological diversity in 5 Algerian Opuntia species. The number of the descriptors was high if compared to previous studies in Cactaceae with 24 descriptors: seven describing the cladode (length, width, thickness, ratio length/width, number of areoles in the central row, number of spines per areole, length of the longest spine), three for the flower (number of flowers per 
cladode, length of the flower, number of stigma lobes) and 14 related to the fruit (length, maximum diameter, ratio length/maximum diameter, density of areoles, peduncle length, depression of receptacle scar, receptacle diameter, peel thickness, peel weight, pulp weight, ratio weight of $\mathrm{peel} /$ fruit weight, number of normal seeds, number of abortive seeds, total soluble solids ( ${ }^{\circ} \mathrm{Brix}$ ) in Gallegos-Vázquez et al. (2011), 27 descriptors from cladodes, flowers and fruits were measured in Gallegos-Vázquez et al. 2012 and 23 descriptors in Mejía et al. (2013).

According to the analysis performed, only few descriptors have shown an effective discriminating capacity. Two quantitative descriptors (length of flower and length of the longest spine per cladode,) and six qualitative descriptors (following: time of beginning of flowering, time of harvest maturity, spine main color, main color of fruit surface, color of fruit flesh, firmness of fruit flesh) have been identified as differential parameters in Opuntia ficus-indica, Opuntia amyclaea, Opuntia streptacantha, Opuntia robusta and Opuntia engelmannii (Table 3). These descriptors ranked within the primary list established by the UPOV for the characterization of Opuntia species (UPOV, 2006).

In comparison with other results, five variables were found to be significant to discriminate forty three accessions (Opuntia ficus-indica) fruit weight, peel weight, pulp weight, juice weight and peel thickness were considered as the most discriminative traits (Chalak et al.2014), Three variables were selected as significant to discriminate twenty nine cactus pear varieties and four xoconostle varieties: peel thickness, pulp weight and to a lesser extent the diameter of the receptacle were the most discriminating of the UPOV guidelines traits (Gallegos-Vázquez et al. 2011). Moreover, spine number, margin hardness and areole distance were selected the three major variables to discriminate between three populations of Hylocereus Britton \& Rose spp. (Mejía et al. 2013). In addition, ten morphological descriptors including; recepticular scar diameter, seed number, pulp weight, cladodes shape, spines, fruits number, fruits size, recepticular scar position, peel and pulp color were registered to be significant to discriminate Opuntia ficusindica and Opuntia amyclaea (Erre \& Chessa 2013).

It has been reported that phenotypic differences between populations can be linked to environmental and genetic variables (Muñoz-Urias et al. 2008). Additionally, Reyes-Agüero (2005), reported the elements of the syndrome of domestication in Opuntia and many traits are of primary interest for human utilization and have had a clear effect on domestication (GallegosVázquez et al.2012). The use of morphological descriptors comprising cladode, flower and fruit traits yielded a high number of morphotypes and allowed the discrimination of all of the studied species. In previous studies, the discrimination level was found to be as high as those reported by other studies using molecular markers for Opuntia spp (Labra et al. 2003, García-Zambrano et al. 2006, Zoghlami et al. 2007, García-Zambrano et al. 2009, Caruso et al. 2010, Majure et al. 2012, El-Banna et al. 2013, Valadez-Moctezuma et al.2014, Ganopoulos et al.2015, Samah et al.2016).

Multivariate analyses based on morphological characters are continuously providing valuable information allowing the breeder to improve the species selected from specific geographical regions (Souza \& Sorrells 1991). Previously, the multivariate techniques have been applied in Opuntia aiming at the morphological and the agronomic descriptions (Reyes-Agüero et al. 2005, Peña-Valdivia et al. 2008) and the industrial (Hammouch et al. 2013).

In our case, multivariate analyses have shown that the highest amount of variation was attained using fruits descriptors (Table 3). These were previously shown as the most important characters for the description of the species (Valdez-Cepeda et al. 2003, Reyes-Agüero et al. 2005, Gallegos-Vázquez et al. 2012).

Morphological descriptors were identified as powerful tools in providing meaningful data on the qualitative and the quantitative aspects in some Opuntia species. Morphological characterization is needed to provide the users with valuable information on individual accessions, relationship among traits, and the structure of collections.

In this study, we managed to provide insights on the level of polymorphism and the structuring of the diversity in five Opuntia species from the Algerian steppes using 49 UPOV morphological and phenological descriptors.

These results may contribute to the best management of the genetic diversity in Opuntia spe- 
cies from Algeria throughout the establishment of a core-collection sheltering representatives from interesting species that best exhibit variation, and this would be a benefit for conservation and for future breeding programs.

\section{Literature cited}

Arteaga MC, Bello-Bedoy R, León de la Luz JL, Delgadillo J, Dominguez R. 2015. Phenotypic variation of flowering and vegetative morphological traits along the distribution for the endemic species yucca capensis (Agavaceae). Botanical Sciences 93: 765-770. DOI: 10.17129/botsci.214

Barbera G. 1995. History, economic and agro-ecological importance. In: Barbera G, Inglese P, PimientaBarrios E. eds. Agro-ecology, Cultivation and Uses of Cactus Pear. FAO Plant Production, Protection Paper. Rome: I-II.

Caruso M, Currò S, Casas GL, Malfa SL, Gentile A. 2010. Microsatellite markers help to assess genetic diversity among Opuntia ficus indica cultivated genotypes and their relation with related species. Plant Systematics and Evolution 290: 85-97. DOI: 10.1007/s00606-010-0351-9

Chalak L, Younes J, Rouphael S, Hamadeh B. 2014. Morphological characterization of prickly pears (Opuntia ficus indica (L.) Mill.) cultivated in Lebanon. International Journal of Science and Research 3: 2541-2553.

El-Banna A, El-Nady M, Dewir Y, El-Mahrouk M. 2013. Stem fasciation in cacti and succulent species-tissue anatomy, protein pattern and RAPD polymorphisme. Actabiologica Hungarica 64: 305-318. DOI: 10.1556/abiol.64.2013.3.4

El Finti A, El boullani R, Fallah M, Msanda F, El mousadik A. 2013. Assessment of some agro-technological parameters of cactus pear fruit (Opuntia ficus-indica Mill.) in Morocco cultivars. Journal of Medicinal Plants Research 7: 2574-2583. DOI: 10.5897/JMPR12.1236

Erre P, Chessa I. 2013. Discriminant analysis of morphological descriptors to differentiate the Opuntia genotypes. ISHS Acta Horticulturae 995: VII International Congress on Cactus Pear and Cochineal 995: 43-50.

Gallegos-Vázquez C, Barrientos-Priego AF, Reyes-Agüero JA, Núñez-Colín CA, Mondragón-Jacobo C. 2011. Clusters of commercial varieties of cactus pear and xoconostle using UPOV morphological traits. Journal of the Professional Association for Cactus Development 13: 10-22.

Gallegos-Vázquez C, Scheinvar L, Núñez-colín CA, Mondragón-Jacobo C. 2012. Morphological diversity of xoconostles (Opuntia spp.) or acidic cactus pears: a Mexican contribution to functional foods. Fruits 67: 109-120.

Ganopoulos I, Kalivasc A, Kavroulakise N, Xanthopouloua A, Mastrogiannia A, Koubouris G, Panagiotis Madesis P. 2015. Genetic diversity of Barbary fig (Opuntia ficus-indica) collection in Greece with ISSR molecular markers. Plant Gene 2: 29-33. DOI: 10.1016/j.plgene.2015.04.001

García-Zambrano EA, Gutierrez-Diez A, Salinas-García GE, Cárdena-Cerda E, Vázquez-Alvarado RE, Zavala-García F, Mártínez de la Cerda J. 2006. Clasificación y estimación de la diversidad genética de Nopal Opuntia spp en base a descriptores fenotípicos y marcadores genético moleculares. Phyton, International Journal of Experimental Botany 75: 125-135.

García-Zambrano EA, Zavala-García F, Gutiérrez-Diez A, Ojeda-Zacarías MC, Cerda-Hurtado I. 2009. Estimation of the genetic diversity of Opuntia spp. using molecular markers AFLP. Phyton, International Journal of Experimental Botany 78: 117-120.

Hadj Sadok T, Aid F, Doumandji A, Bellal M. 2014. Effet du jus de cladodes d'Opuntia ficus indica sur la fermentation du lait et la croissance des bactéries lactiques et probiotiques. Nature et Technologie 11: 17-29.

Hammouch H, Dermaj A, Chebabe D, Decaro P, Hajjaji N, Bettach N, Takenouti H, Srhiri A. 2013. Opuntia ficus indica Seed Oil: Characterization and Application in Corrosion Inhibition of Carbon Steel in Acid Medium. Analytical \& Bioanalytical Electrochemistry 5: 236-254.

Kiesling R. 1999. Domesticacióny distribution Opuntia ficus-indica. Journal of the Professional Association for Cactus Development 3: 50-59.

Labra M, Grassi F, Bardini M, Imazio S, Guiggi A, Citterio S, Banfi E, Sgorbati S. 2003. Genetic relationships in Opuntia Mill. genus (Cactaceae) detected by molecular marker Plant. Science 165: 1129-1136. DOI: $10.1016 / \mathrm{s} 0168-9452(03) 00321-2$

Lamine M, Zemni H, Ziadi S, Chabaaane A, Melki I, Mejri S, Zoghlami N. 2014. Multivariate analysis and clustering reveal high morphological diversity in tunisian autochthonous grapes (Vitis vinifera): insights into characterization, conservation and commercialization. Journal international des sciences de la vigne et du vin 48: 1-12. 10.20870/oeno-one.2014.48.2.1565

Le Houérou, H.N. 1996a. The role of cacti (Opuntia spp.) in erosion control, land reclamation, rehabilitation and agricultural development in the Mediterranean Basin. Journal of Arid Environments 33: 135159. doi.org/10.1006/jare.1996.0053 
Received:

August 17th, 2016

Accepted:

March 21st, 2017
Mejía HA, Muriel-Ruiz SB, Montoya CA, Reyes-Sequeda C. 2013. In situ morphological characterization of Hylocereus spp. (fam.: Cactaceae) genotypes from antioquia and córdoba (colombia). Revista Facultad Nacional de Agronomia 66: 6845- 6854.

Majure LC, Judd WS, Soltis PS, Soltis DE. 2012. Cytogeography of the Humifusa clade of Opuntias. s. (Cactaceae: Opuntioideae): Correlations with geographic distributions and morphological differentiation of a polyploid complex. Comparative Cytogenetics 6: 53-77. DOI: 10.3897/CompCytogen. v6i1.2523

Martínez-González CR, Gallegos-Vazquez C, Luna-Vega I, García-Sandoval R. 2015. Opuntia leiascheinvariana, una nueva especie de Cactaceae del estado de Hidalgo, México. Botanical Sciences 93: 517 529. DOI: http://dx.doi.org/10.17129/botsci.247

Muñoz-Urias C, Palomino-Hasbach G, Terrazas T, García-Velázquez A, Pimienta-Barrios E. 2008. Variación anatómica y morfológica en especies y entre poblaciones de Opuntia en la porción sur del desierto chihuahuense. Boletín de la Sociedad Botánica de México 83: 1-11.

Neffar S, Beddiar A, Redjel N, Boulkheloua J. 2011. Effects of the age of prickly pear (Opuntia ficus indica f. inermis) plantations on soil properties and vegetation at Tebessa (semi arid area of eastern Algeria). International Journal of Mediterranean Ecology 37: 5-15.

Peña-Valdivia CB, Luna-Cavazos M, Carranza-Sabas JA, Reyes-Agüero JA, Flores A. 2008. Morphological characterization of Opuntia spp.: A Multivariate Analysis. Journal of the Professional Association for Cactus Development 10: 1-21.

Rebman JP, Pinkava DJ. 2001. Opuntia cacti of North Americaan overview. Florida Entomological Society 84: 474-483.

Reyes-Agüero JA, Aguirre-Rivera JR, Flores-Flores JL. 2005. Variación morfológica de Opuntia (Cactaceae) en relación con su domesticación en la Altiplanicie Meridional de México. Interciencia 30: 476-484.

Samah S, De Teodoro-Pardo CV, Serrato-Cruz MA, Valadez-Moctezuma E. 2016. Genetic Diversity, Genotype Discrimination, and Population Structure of Mexican Opuntia sp., Determined by SSR Markers. Plant Molecular Biology Reporter 34:146-159. DOI:10.1007/s11105-015-0908-4

Souza E, Sorrells ME. 1991. Relationships among 70 North American oat germplasms: I. Cluster analysis using quantitative characters. Crop Science 31: 599-605. DOI: $10.2135 /$ cropsci1991.0011183x003100 030010x

Taylor NP. 1997. Cactaceae. In: Oldfield S. (compiler). Cactus and Succulent Plants-Status International Union for Conservation of Nature and Natural Resources. IUCN, Gland, Switzerland and Cambridge UK. 17-20.

Uchoa AF, Souza PAS, Zarate RML, Gomes-Filho E, Campos FAP. 1998. Isolation and characterization of are serve protein from the seeds of Opuntia ficus-indica (Cactaceae). Brazilian Journal of Medical and Biological Research 31: 757-761. 10.1590/S0100-879X1998000600005

UPOV. 2006. Cactus Pear and Xoconostles (Opuntia, Groups 1 \& 2), Guidelines for the Conduct of Tests for Distinctness, Uniformity and Stability. TG/217/2. International Union for the Protection of New Varieties of Plants. Geneve.

Valdez-Cepeda RD, Blanco-Macías F, Gallegos-Vázquez C. 2003. Ordering and numerical classification in prickly pear cactus using fruit attributes. Revista Chapingo Serie Horticultura 9: 81-95.

Valadez-Moctezuma E, Ortiz-Vásquez Q, Samah S. 2014. Molecular based assessment of genetic diversity of xoconostle accessions (Opuntia spp.). African Journal of Biotechnology 13: 202-210. DOI: 10.5897/ AJB2013.13350

Wang X, Felker P, Burrow MD, Paterson AH. 1998. Comparison of RAPD marker with morphological and physiological data in the classification of Opuntia accessions. Journal of the Professional Association for Cactus Development 3: 1-5.

Ward JHJr. 1963. Hierarchical grouping to optimize an objective function. Journals - American Statistical Association 58: 236-244. DOI: $10.2307 / 2282967$

Williams WT. 1976. Pattern Analysis in Agricultural Science. Elsevier Scientific Publishing Company, Amsterdam, The Netherlands.

Zoghlami N, Chrita I, Bouamama B, Gargouri M, Zemni H, Ghorbel A, Mliki A. 2007. Molecular based assessment of genetic diversity within Barbary fig (Opuntia ficus indica (L.) Mill.) in Tunisia. Scientia Horticulturae 113: 134-141. DOI: 10.1016/j.scienta.2007.02.009 